\title{
Effects of AFTA on Poverty : Evidence from Laos
}

\section{Phouphet Kyophilavong}

National University of Laos, Vientiane, Lao PDR

Richard Record

World Bank, Vientiane, Lao PDR

Shinya Takamatsu

World Bank, Washington DC, United States

Konesawang Nghardsaysone

World Bank, Vientiane, Lao PDR

Inpaeng Sayvaya

Champasack University, Champasack Province, Lao PDR

\begin{abstract}
The Association of South-East Asian Nations Free Trade Agreement plays an important role in regional economic development. However, Association of South-East Asian Nations Free Trade Agreement's contribution to poverty reduction remains unclear. Therefore, the main objective of this study is to assess the impact of Association of South-East Asian Nations Free Trade Agreement on poverty using Laos as a case study. To do so, we apply a Computable General Equilibrium model, microsimulation, and a

\footnotetext{
* Corresponding Author: Phouphet Kyophilavong; National University of Laos, 7322, NUoL, FEB, Dongdok, Vientiane, Lao PDR; Tel: +856-21-770067, Fax: +856-21-740874, E-mail: phouphetkyophilavong@gmail.com.

Co-authors: Richard Record; World Bank, Patou Xay, Nehru Road, Vientiane, Lao PDR, Tel: +856-21-266 200, E-mail: rrecord@worldbank. org.

Shinya Takamatsu; World Bank, 1818 H Street NW, Washington DC, 20433, Tel: +1 202-473-4709, E-mail: stakamatsu@ worldbank.org.

Konesawang Nghardsaysone; World Bank, Patou Xay, Nehru Road, Vientiane, Lao PDR, Tel: +856-21- 266 200, E-mail: knghardsaysone@worldbank.org.

Inpaeng Sayvaya; Champasack University, Lao PDR, Pakse District, Champasack Province, Lao PDR, Tel: +856-31-260157, E-mail: inpaengsayvaya@gmail.com.
} 
logit model. Laos benefits from Association of South-East Asian Nations Free Trade Agreement but has also experienced an increase in its trade deficit. The primary benefits from Association of South-East Asian Nations Free Trade Agreement derive from the improvement in trade facilitation and a significant increase in Foreign Direct Investment. Association of South-East Asian Nations Free Trade Agreement may also reduce income inequality at the national level. However, Association of South-East Asian Nations Free Trade Agreement could cause disparities between the so-called winners and losers. The beneficiaries of Association of South-East Asian Nations Free Trade Agreement might be limited to households that have access to land, irrigation, road, and electricity.

\section{JEL Classifications: F15, F17}

Keywords: Association of South-East Asian Nations, Computable General Equilibrium Model, Laos, Microsimulation

\section{Introduction}

The impact of trade liberalization on growth and poverty is of major interest to academics and policymakers. Empirical studies show that trade is important for stimulating economic growth and structural change, which, in turn, can lead to higher incomes and the reallocation of production and consumption (Winter 2004, Dollar 1992, Frankel and Rose 1999). However, some questions still exist as to whether or not trade liberalization is beneficial for poor households.

The Lao People's Democratic Republic (hereafter Laos) is a Least Developed Country (LDC) in economic transition, and a large development gap exists between Laos and other countries (Kyophilavong et al. 2013). Laos' national development goal is to graduate from LDC status by the year 2020, while balancing economic, social, and environmental issues (The Government of Laos 2004, 2006). It is liberalizing trade to increase economic growth and reduce poverty. As one of its most significant steps toward trade liberalization, Laos joined the Association of South-East Asian Nations Free Trade Area (AFTA) in 1998.

Laos has achieved economic growth in the past decade along with remarkable poverty reduction. However, Laos still faces various economic problems. Despite 
reducing poverty gradually, its level is still high, especially in rural areas, and inequality has increased (World Bank and DOS 2009). Therefore, some questions persist concerning whether trade liberalization efforts such as AFTA will exacerbate or alleviate poverty in Laos. In fact, the agreement could have both positive and negative impacts on poverty, depending on changes in household income, factor markets, and household and commodity markets (Winter 2004, Ravallion and Lokshin 2008). However, very few studies have focused on AFTA's impact on poverty in Laos. Most studies are descriptive analyses that do not use comprehensive economic models (Athukorala and Menon 1997).

Given the fact that research on these issues is so limited, the impact of AFTA on macroeconomic variables and poverty is still unclear. Therefore, we use the Computable General Equilibrium (CGE) model and microsimulation to analyze the impact of AFTA on macroeconomic variables and poverty in Laos. The results of this study are vital to formulating appropriate policies for gaining the maximum benefits from AFTA.

This study makes three main contributions to the literature. First, it is a pioneering study in linking the CGE model and microsimulation to analyze the impacts. of AFTA on poverty in Laos. Second, we consider the Foreign Direct Investment (FDI) impact and the improvement in trade facilitation from AFTA to capture dynamic trade liberalization impacts. Third, in order to investigate the impacts of AFTA on poverty in more detail, a logit model is used to analyze the factors that influence the winners and losers from AFTA.

This paper is organized as follows. Section II gives an overview of Laos' current economy, trade, and poverty. Section III reviews the key literature related to the subject of trade liberalization under ASEAN and its impacts on poverty. Section IV describes the research method used in this study. Section V presents the results, and Section VI offers the conclusion.

\section{Economy, Trade, and Poverty of Laos}

Since introducing the New Economic Mechanism (NEM) in 1986, Laos has been transitioning from a centrally planned economy to a more market-oriented economy. As a result, except during the Asian financial crisis of the 1990s, Laos has achieved high 
economic growth. Economic growth averaged about 8.02\% over the 2006 2013 period, which is faster than that in the previous periods of 1990 1995 (6.28\%), 1996 2000 (6.17\%), and 2001 2005 (6.24\%).

Even though Laos has maintained high economic growth, low inflation, and a stable exchange rate, serious macroeconomic challenges remain. First, Laos faces chronic twin deficits in government and trade balances. Second, a huge gap exists between savings and investment. The savings rate is low because average incomes are low. Third, it also faces a high external debt burden. Fourth, because Laos' economy heavily depends on its resource sectors, ${ }^{2}$ growth in other sectors is limited, thereby causing a negative long-term impact, known as the Dutch disease.

The national goal of Laos is to eradicate poverty by 2020. To achieve this, the Lao government has implemented the National Growth and Poverty Eradication Strategy (NGPES), which is an overall development and poverty alleviation framework (The Government of Laos 2004). The World Bank and Department of statistics (2009) show that the incidence of poverty has fallen from $46 \%$ in 1993 to $39 \%$ in 1998 and further to $33.5 \%$ in 2003 and to $28 \%$ in 2008 . Inequality has also been reduced since 1993 . The Gini coefficient index increased from $30.5 \%$ in 1993 to $34.9 \%$ in 1998 . However, the index declined to $32.6 \%$ in 2003 and increased to $35.4 \%$ in 2008 .

Prior to 1986, the Lao government controlled foreign trade. The government used a battery of interventions, including foreign exchange controls, protective tariffs, and import restrictions, to rescue its declining foreign exchange reserves. It monopolized both exports and imports, except the trade carried out by joint public and private companies or a few state enterprises. However, the government liberalized the external trade system in 1987, which resulted in the elimination of most restrictions on trade in 1988.

Together with continued domestic liberalization, Laos has integrated into the regional and global economies. Laos joined ASEAN in 1997 for geopolitical and economic development and has gradually integrated into ASEAN over time. The agreement on the Common Effective Preferential Tariff (CEPT) scheme for AFTA required Laos to eliminate all import duties by 2015 .

The trade trends indicate that Laos has faced a chronic trade deficit since introducing

\footnotetext{
The engine of growth during this period was FDI inflows in the mining and hydroelectricity sectors through production and exports. For a more detailed discussion of the impact of FDI on these sectors on the Lao economy, see Kyophilavong and Toyoda (2008).

2 According to the World Bank (2010), the resource sector contributed about $2.5 \%$ points to the growth rate from 2005 to 2010 . The resources sector accounted for about $70 \%$ of all exports in 2010, a share that is expected to increase under expected ongoing development in the hydroelectricity and mining sectors. Revenues from the resource sector as a share of total revenues rose to $2.6 \%$ of GDP in 2010, a share that is expected to rise in future.
} 
the NEM in 1986, although the situation has recently changed. Laos imports various goods from other countries, ranging from light and heavy manufacturing goods to processed food, textiles, and clothing. Imports from Thailand account for $60 \%$ of all imported goods (Oh and Kyophilavong 2014).

Laos' main export commodities in 2008 were textiles and clothing, light manufacturing, and mining products. However, the export structure of the country has since changed. Heavy manufacturing held the highest share of exports in 2008 - higher than textiles, clothing, and mining (Oh and Kyophilavong 2014). The main export destinations are Thailand, the European Union, East Asia, and Vietnam. These export patterns show that Lao trade is highly dependent on Asian countries, especially its neighboring countries.

\section{Literature Review}

The literature review is divided into two parts. The first part examines studies on trade and poverty in other developing countries. The second part discusses studies on trade and poverty in Laos.

A number of studies exist on trade and poverty in other countries. These empirical studies show that trade is important for stimulating economic growth (Winter 2004, Dollar 1992, Frankel and Rose 1999). However, the impact of trade liberalization on poverty is complex, with its effect exerting itself through various channels, such as economic growth and stability, households and markets, wages and employment, and government revenue (Winter 2004, Ravallion 2006, Dollar and Kraay 2004).

A range of studies have examined the impacts of trade liberalization on macroeconomic variables and welfare in Asia, ${ }^{3}$ with a number of studies investigating the impact of AFTA on individual economies in ASEAN. ${ }^{4}$ Of the latter type of studies, Athukorala and Menon (1997) examine the implications of the formation of AFTA for FDI flows and trade patterns in the region. Fukase and Winters (2003) examine the three

\footnotetext{
${ }^{3}$ Lakatos and Walmsley (2012) also estimate the effect of the ASEAN-China free trade agreement using the GTAP model. Abbott (2008) examines the relationship between trade and development in Vietnam by applying the CGE model and finds that trade could foster growth and development in Vietnam.

${ }^{4}$ Adams and Park (1995) pioneer the use of a multi-country CGE model to analyze the impact of AFTA on ASEAN countries.
} 
channels of AFTA that affect growth in new member countries. Heinrich and Konan (2001) analyze the impact of AFTA on foreign investment and find that the reduction of regional trade barriers could create new attractive investment destinations in ASEAN. Khan and Tongzon (2005) estimate the revenues' losses of the Cambodia, Laos, Myanmar, and Vietnam (CLMV countries) as a result of implementing AFTA, finding that the CLMV countries face significant losses in customs' revenues from AFTA. However, government revenues (tax and non-tax) are likely to rise in CLMV countries. In addition, Ariyasajjakorn et al. (2009) analyze five simulation scenarios of ASEAN and ASEAN PLUS on macroeconomic variables and poverty in countries in and outside ASEAN. Their analysis shows that AFTA PLUS tends to increase the output of capitalintensive goods more than labor-intensive goods. Therefore, less-developed countries like Laos tend to receive smaller benefits compared with other countries. Further, AFTA PLUS tends to widen the income gaps between high- and low-income households across ASEAN countries.

Still, very few studies have examined the impact of AFTA on poverty and the Lao economy. Fukase and Martin (1999) use a basic CGE model to assess the effects of joining AFTA on economic development and determine that accession is indeed economically beneficial. Fane (2006) discusses government policies that ensure the benefits of trade liberalization on income distribution. Menon (1999) examines the impact of Laos' membership in AFTA. ${ }^{5}$ Finally, Kyophilavong (2006) uses a CGE model to analyze the potential impact of AFTA on the Lao economy. The simulation results revealed significant benefits from AFTA accession for Laos, especially in nonagriculture sectors. Nevertheless, this model involved only two sectors and did not analyze the impacts of AFTA on poverty and income distribution.

In summary, while several quantitative studies on AFTA in Laos have been conducted, none of these examine the characteristics of gains and losses from AFTA. This is a major gap in the current policy and research fields for a country facing great obstacles to development after joining AFTA.

\footnotetext{
${ }^{5}$ Menon (1999) finds that (1) Laos is likely to gain low trade diversification but AFTA will be a vehicle for Laos to negotiate market access issues with Thailand; (2) the impact of AFTA on government revenues is likely to be low; and (3) AFTA is likely to increase flows of FDI to Laos because of improvements in its legal, administrative, and institutional frameworks according to ASEAN standards.
} 


\section{Methodology}

Three models are used in this study: the Global Trade Analysis Project (GTAP) model (a form of CGE), microsimulation, and a logit model. First, the GTAP model is used to analyze the impact of trade liberalization on macroeconomic variables. Second, the results of the GTAP model (prices and wages) are used in the microsimulation to analyze the impact of trade liberalization on poverty. Lastly, the logit model identifies the factors that affect household welfare gains.

\section{A. GTAP model}

For our analysis, we use the GTAP model, which is a form of CGE model. A CGE model combines economic theory and empirical data to create an economic tool for policy analysis such as changes in tariffs and their effects on economic systems as a whole. CGE models present the behavior of economic agents (producers, consumers, and government), sectors (industry, agriculture, and services), and factors of production (labor, capital, and land) and come in two basic types: multi-region CGE models and single country CGE models (Hertel 1997).

The GTAP model is a multi-region model and is one of the most popular models for analyzing the impact of trade policies. There are various advantages to the GTAP model. First, because it is a multi-region model of world production and trade, it can take into account the overall trade implications of AFTA as well as third-party countries. Second, it contains a database for different sectors and thus can explore the trade implications for various sectors of interest. ${ }^{6}$ The latest version of the GTAP database, version 8 , is used in this study. To facilitate our analysis, regions are aggregated into 21 separate sub-regions. All 57 sectors remain as delineated in the GTAP database.

The model's closure and free parameters are important factors that influence the model's simulation results. The closure divides the variables into endogenous or exogenous variables. Some studies find that different parameters lead to different policy results (Abler et al. 1999). International trade is linked through the Armington

\footnotetext{
${ }^{6}$ For more details, see Hertel (1997). A graphic presentation of the GTAP model, with particular emphasis on the accounting relationships, is given by Brockmeier (1996).
} 
substitution of goods differentiated by country of origin. The trade liberalization simulation produces a positive or negative impact depending on the Armington elasticities (Zhan and Verikios 2006). Basically, some parameters for this study are calibrated by SAM. However, some parameters for the GTAP model are not available in Laos because estimation of a free parameter is not possible for Laos.

\section{B. Measuring welfare impacts}

Household welfare is affected by four factors: changes in revenue, expenditures, inputs, and wages (see equation below). As mentioned in the research framework, the measurement of welfare changes as a result of trade liberalization uses the topdown approach linked to the GTAP model and microsimulation. There are two steps to estimating the effect of trade liberalization on household welfare. First, we estimate producer and consumer price changes, as well as price changes in the factors of production from the GTAP model. Second, the price and output changes from the GTAP model are used for the microsimulation. The household welfare change is calculated using Equation (1) in Chen and Ravallion (2004) and Ravallion and Lokshin (2008).

The results of the GTAP model indicate that the four factors are influenced by changes in wages and consumer and producer prices. Changes in price and production of particular food and non-food items alter household welfare, which is based on a share of revenue from these items. Changes in international demand for particular goods affect household incomes, which depend on a proportion of their marketed production of goods. Wage changes influence household income according to the share of wage income received. Price changes also affect household consumption, with price increases reducing household welfare. Welfare impacts resulting from trade liberalization in terms of the monetary value of utility changes for household income can be expressed as follows :

\footnotetext{
${ }^{7}$ We use some free parameters from Warr (2007) for our estimation.

${ }^{8}$ The measurement of the welfare impacts from trade liberalization has some constraints. First is data constraints because the initial data on price and wage levels are not included. Second, this problem can be overcome by calculating a first-order approximation of the welfare impact in a neighborhood of the household's optimum (Chen and Ravallion 2004, Ravallion and Lokshin 2008).
} 


$$
g_{\mathrm{i}}=\sum_{j=1}^{57}\left[p_{i j}^{s} q_{i j}^{s} \frac{d p_{i j}^{s}}{p_{i j}^{s}}-p_{i j}^{d}\left(q_{i j}^{d}+z_{i j}\right) \frac{d p_{i j}^{d}}{p_{i j}^{d}}\right]+\sum_{k=1}^{2}\left(w_{k} L_{i k}^{s} \frac{d w_{k}}{w_{k}}\right)
$$

$=($ change in revenue $)-($ change in expenditure $)-($ change in input $)+($ change in wage $)$

where

$g_{i} \quad=$ Monetary value of the change in utility for household $i$;

$p_{i j}^{s} q_{i j}^{s}=$ Revenue (selling value) from household production activities in sector $j$;

$p_{i j}^{s} \quad=$ Supply price from household $i$ in production activities in sector $j$

$q_{i j}^{s} \quad=$ Quantity supplied from household $i$ in production activities in sector $j$;

$p_{i j}^{d}\left(q_{i j}^{d}+z_{i j}\right)=$ Weight (negative) for demand price changes;

$p_{i j}^{d} \quad=$ Demand price from household $i$ in production activities in sector $j$;

$q_{i j}^{d} \quad=$ Quality demanded from household $i$ production activities in sector $j$;

$z_{i j} \quad=$ Commodities used as production inputs, of which $z_{i j}$ is used for production goods in sector $j$;

$w_{k} L_{i k}^{s}=$ Weight of changes in the wage rate for activity $k$;

$w_{k} \quad=$ Wage rate to activity $k$; and

$L_{i k}^{s} \quad=$ Household's external labor supply to activity $k$.

To link the results from the GTAP model, we conduct data matching between the GTAP database and the fourth Lao Expenditure and Consumption Survey. ${ }^{9}$ First, we match the 57 sectors of production and consumption in the GTAP database with the 356 categories of consumption and 117 categories of production in the Lao Expenditure and Consumption Survey (LECS4). Second, we undertake the reconciliation of labor. Third, household income is reconciled. Finally, poverty line income is reconciled.

\section{Factors affecting welfare}

To analyze the detailed impacts on households, we use a logit model to investigate the factors that influence the absolute gains or losses in welfare. The dependent variable for welfare is $G i$. If a household gains from AFTA, the variable equals one and is zero otherwise.

\footnotetext{
${ }^{9}$ See data matching details in Kyophilavong and Takamatsu (2011) and Chen and Ravallion (2004).
} 
Following Anderssson et al. (2005), Warr (2010), and Chen and Ravallion (2003), the explanatory variables can be divided into three categories: factors of production, household characteristics, and environmental factors. The logit relation between the probability of a gain or a loss in welfare and the explanatory variables can be expressed as follows:

$$
\begin{gathered}
G i=\alpha+\beta_{i} V_{i}+\gamma_{i} W_{i}+\delta_{i} X_{i}+\varepsilon \\
\operatorname{Prob}(G i=1)=\frac{1}{1+e^{-G_{i}}}
\end{gathered}
$$

where

Prob $=$ Probability of gains in household welfare $(G i)$;

$e^{-G_{i}}=$ Irrational number to the power of $G i$

$G i=G i$ equals one if household gains in welfare from AFTA and is zero otherwise;

$V=$ Vectors of factors of production;

$W \quad=$ Household characteristics; and

$X=$ Environmental factors.

$\alpha, \beta_{i}, \gamma_{i}$, and $\delta_{i}$ are unknown parameters, and $\varepsilon$ is a normally distributed random error term.

In the factors of production, the choice of variables reflect the production capacities of households and include the inputs of land, physical capital, technology, human capital, and labor (variables' definitions are provided in Appendix 1). Land area is an important factor in determining household welfare. We include two categories of land: farmland and land for other agriculture. Physical capacity is difficult to measure. Following the literature, physical capital includes cattle, buffaloes, and pigs. Human capital is one of the most crucial factors in determining welfare. We use the education level of the household's adult members as a proxy for human capital. Technology is also an important factor in determining household welfare. We include two variables as proxies for technology: chemical fertilizers and whether the household runs a business.

The household characteristics are also important factors in determining household welfare. Therefore, we include ages, dependency ratio, ${ }^{10}$ and gender of the household

\footnotetext{
${ }^{10}$ Dependency ratio is calculated by dividing the number of dependents by the total number of household members.
} 
head. Environmental factors refer to the impact of infrastructure on the household's income-earning capacity. We include six variables to capture the impact of infrastructure: village-level access to electricity, roads, health services, ${ }^{11}$ safe water, and markets. ${ }^{12}$

\section{Simulation design}

We show the possible impacts of AFTA on the Lao economy through four simulation scenarios as follows:

-Simulation scenario 1: Reduced tariff rate

Following the CEPT scheme for AFTA, we assume that tariff rate is reduced to $0 \%$ in all sectors for all ASEAN members. ${ }^{13}$

-Simulation scenario 2: Improvement in trade facilitation

Improvement of trade facilitation from AFTA is one of the most important factors for promotion of trade and investment in Laos. The effects of an improvement in trade facilitation and in time costs will reduce the overall trade costs. This approach is followed by Hertel, Walmsley, and Itakura (2001); Minor and Tsigas (2008); and Stone and Strutt (2009). Following the literature, we assume a 25\% reduction in time costs in the Lao economy.

-Simulation scenario 3: Promotion of FDI

Trade liberalization could promote FDI (Brown and Stern 2001, Binh and Haughton 2002). By improving institutions and thereby the climate for doing business, AFTA might bring increased FDI to Laos. Following the trends of increasing FDI and key interviews, we assume that the FDI inflow will increase by about $15 \%$.

-Simulation scenario 4: Overall impact of AFTA

Simulation scenario 4 combines simulation 1 through simulation 3 as an overall simulation of the impacts of AFTA on the Lao economy.

\footnotetext{
${ }^{11}$ We use two variables to capture the village's access to health services: whether the village has community health works and the village's distance to a hospital.

${ }^{12}$ To calculate access to a market, whether the village has its own market is considered a variable.

${ }^{13}$ We do not consider the effects from the service sector
} 


\section{Results}

Simulation 4 indicates that AFTA has a positive impact on an increasing Equivalent Variation (EV), real Gross Domestic Product (GDP), and terms of trade. However, it negatively impacts the trade balance. The increase in EV is about 422 million US dollars. The increased EV is mostly the result of the allocative efficiency effect. ${ }^{14}$ The GDP quantity index increases by $9.5 \%$, and the terms of trade increase by $3 \%$. However, this latter variable has a negative impact on the trade balance of about 19\% (Table 1). The effect of AFTA via the tariff cut alone does not have much of a positive impact on the Lao economy in terms of GDP and EV. However, the larger impact from AFTA comes from improvements in trade facilitation (simulation 2) and increased FDI from improvements in the business climate (simulation 3). These results show that the impacts resulting from improvements in trade facilitation and promotion of FDI are larger than those from tariff reduction.

Table 1. Impact on macroeconomic variables

\begin{tabular}{|l|c|c|c|c|}
\hline & Simulation 1 & Simulation 2 & Simulation 3 & Simulation 4 \\
\cline { 2 - 5 } & $\begin{array}{c}\text { Reduced } \\
\text { tariff rate }\end{array}$ & $\begin{array}{c}\text { Improvement } \\
\text { in trade } \\
\text { facilitation }\end{array}$ & $\begin{array}{c}\text { Promotion of } \\
\text { Foreign Direct } \\
\text { Investment }\end{array}$ & $\begin{array}{c}\text { Overall } \\
\text { impact of } \\
\text { AFTA }\end{array}$ \\
\hline $\begin{array}{l}\text { Equivalent } \\
\text { variation (US dollar) }\end{array}$ & 13.61 & 219.42 & 189.51 & 422.53 \\
\hline GDP index (\%) & 0.12 & 3.1 & 6.79 & 9.5 \\
\hline Trade balance (US dollar) & -32.41 & -59.22 & 72.84 & -18.79 \\
\hline Terms of trade (\%) & 0.56 & 5.21 & -2.34 & 3.43 \\
\hline
\end{tabular}

(Source) Authors' GTAP model results.

\footnotetext{
${ }^{14}$ There are basically four major sources for any welfare change: allocative efficiency, endowment, technology, and terms of trade (Hanslow 2000, Adams 2005). The fourth factor is determined by the change in equity income from ownership of capital endowments and can be broken down as changes in three factors: domestic capital shock, household income earned on capital abroad, and domestic capital owned by foreigners.
} 
Using the simulated price and output changes based on the GTAP model, the predictions regarding changes in welfare and poverty are created using the LECS 4. Table 2 summarizes the results of the microsimulation. The first panel in the table shows the mean change in welfare for households from AFTA in terms of rural and urban regions.

As the table depicts, all numbers are negative, which means that, on average, Lao households are net buyers rather than sellers. The fourth column indicates that estimated per capita welfare changes. AFTA increases welfare in Laos by $11.85 \%$ on a national level. However, the direction of the welfare change in rural areas is larger than in urban areas $(20.09 \%$ in rural areas versus $6.20 \%$ in urban areas). In the panel, we estimate the welfare changes by region (north, central, and south); all regions gain from AFTA. However, households in the south of Laos experience the most gains compared with other regions.

The second panel in the table shows the change in economic inequality because of AFTA by using the Gini index. ${ }^{15}$ We find AFTA influences reduction in inequality on a national level, although the change is relatively small. Inequality in rural areas increases slightly. Moreover, we predict that inequality in urban areas will only slightly decrease. Inequality across regions and in Vientiane decreases but increases in other regions. These findings indicate that the inequality changes from AFTA are heterogeneous across regions.

The third panel shows the poverty impacts of AFTA. Poverty increases about $3.81 \%$ at the national level. ${ }^{16}$ On a sub-national level, however, poverty drops in rural areas but increases in urban areas. This finding indicates AFTA has a heterogeneous impact on poverty.

As discussed in this section, AFTA's impacts on welfare are positive on a national level for urban and rural households. In addition, welfare increases across all regions. Furthermore, AFTA reduces inequality on the national level, but its impacts on inequality are heterogeneous across the regions. Although AFTA might increase poverty as measured by expenditures, such changes are relatively small.

There are three main reasons for increased welfare in rural households rather than in urban ones: increases in wages, lower prices for production goods, and increases in the prices of agricultural products. Rural areas gain more wage income (unskilled labor) in

\footnotetext{
${ }^{15}$ Here, it is important to note that we use household expenditure to calculate the Gini index.

${ }^{16}$ It is important to note that we use household expenditure to calculate the headcount index. The poverty line was set at the $\$ 1.25$ poverty line, which amounts to 142,181.56 kip per month (\$38) for 2005, which is based on Engvall et al. (2009).
} 
the agricultural sector as a result of AFTA than urban areas. AFTA leads to lower prices for necessary consumption goods, such as those used in food production, agricultural machinery, and other manufacturing goods. The agriculture sector is mainly located in rural areas. Therefore, rural areas might benefit from increased revenue because of increases in crop prices brought about by AFTA.

Table 2. Results of the microsimulation

\begin{tabular}{|c|c|c|c|}
\hline \multicolumn{4}{|c|}{ 1. Mean welfare change } \\
\hline & Baseline & Simulated & Change (\%) \\
\hline & per capita (kip) & per capita (kip) & in percentage \\
\hline National & $-614,737$ & $-541,908$ & 11.85 \\
\hline Rural & $-332,467$ & $-265,662$ & 20.09 \\
\hline Urban & $-1,467,895$ & $-1,376,859$ & 6.20 \\
\hline Region & & & \\
\hline Vientiane (capital city) & $-2,961,939$ & $-2,867,558$ & 3.19 \\
\hline North & $-499,082$ & $-460,666$ & 7.70 \\
\hline Central & $-912,230$ & $-877,969$ & 3.76 \\
\hline South & 687,737 & 874,479 & 27.15 \\
\hline \multicolumn{4}{|c|}{ 2. Gini index as percentage } \\
\hline & Baseline & Simulated & Change (\%) \\
\hline National & 45.26 & 44.88 & -0.39 \\
\hline Rural & 44.56 & 45.32 & 0.76 \\
\hline Urban & 45.87 & 44.15 & -1.72 \\
\hline \multicolumn{4}{|l|}{ Region } \\
\hline Vientiane (capital city) & 48.03 & 44.17 & -3.86 \\
\hline North & 43.84 & 44.22 & 0.38 \\
\hline Central & 42.88 & 45.08 & 2.20 \\
\hline South & 42.37 & 46.35 & 3.99 \\
\hline \multicolumn{4}{|c|}{ 3. Poverty impacts (headcount index, percentage) } \\
\hline & Baseline & Simulated & Change (\%) \\
\hline National & 25.78 & 29.59 & 3.81 \\
\hline Rural & 29.65 & 29.04 & -0.62 \\
\hline Urban & 20.26 & 30.38 & s10.12 \\
\hline
\end{tabular}




\begin{tabular}{|l|c|c|c|}
\hline Region & \multicolumn{3}{|c|}{} \\
\hline Vientiane (capital city) & 16.79 & 28.93 & 12.14 \\
\hline North & 31.77 & 28.21 & -3.56 \\
\hline Central & 27.35 & 32.34 & 4.99 \\
\hline South & 22.18 & 23.37 & 1.19 \\
\hline
\end{tabular}

(Note) Kip is Lao currency.

(Source) Authors' microsimulation model result.

Table 3 contains the results of the logit model. Out of 23 explanatory variables, 13 are statistically significant in determining the absolute gains or losses in welfare $(G i)$, including the factors of production, household characteristics, and environmental factors.

Among factors of production vaiables, all of the variables for human capital are strongly significant, and it appears that household member literacy and the education level of household heads are positively related to welfare. The variables related to technology - chemical fertilizers and whether a household runs a business - appear to have different effects on welfare. The use of chemical fertilizers has a positive and significant effect, but running a business has a negative and significant effect. These findings indicate that households that run businesses lose welfare as a result of AFTA. It is possible that they might lose welfare only in the short term, but in the long term, they gain more benefits as a result of AFTA.

Table 3. Effects of factors on household welfare

\begin{tabular}{|l|r|r|r|}
\hline Dependent variable: $\boldsymbol{G} \boldsymbol{i}$ & Coefficient & $\boldsymbol{z}$-value & $\boldsymbol{P}>|\boldsymbol{z}|$ \\
\hline Explanatory variables & & & \\
\hline Factors of production & & & \\
\hline Irrigation access to village & $0.1448^{*}$ & 1.80 & 0.0720 \\
\hline Number of cattle per household & $0.0226^{* * *}$ & 4.18 & 0.0000 \\
\hline Number of buffaloes per household & $0.0619 * * *$ & 6.44 & 0.0000 \\
\hline Number of pigs per household & $0.0278^{* * *}$ & 4.00 & 0.0000 \\
\hline Total number of literates per household & $0.0476^{* *}$ & 2.21 & 0.0270 \\
\hline Literate females & 0.0451 & 1.53 & 0.1270 \\
\hline Education level of household head in years & $0.0626^{* * *}$ & 9.10 & 0.0000 \\
\hline Adults & 0.0332 & 1.54 & 0.1230 \\
\hline Rice farm land area per household & -0.0121 & -0.71 & 0.4750 \\
\hline
\end{tabular}




\begin{tabular}{|l|r|r|r|}
\hline Other cultivation land area per household & $0.0824 * * *$ & 4.24 & 0.0000 \\
\hline Village located at lowland area & $0.3063^{* * *}$ & 5.61 & 0.0000 \\
\hline Chemical fertilizers & $0.2088^{* *}$ & 2.63 & 0.0090 \\
\hline Business & $-0.1798^{* * *}$ & -3.08 & 0.0020 \\
\hline Household characteristics & & & \\
\hline Dependency ratio & -0.1270 & -1.24 & 0.2140 \\
\hline Male head of household & 0.0722 & 0.69 & 0.4880 \\
\hline Age of household head & -0.0053 & -0.44 & 0.6610 \\
\hline Age Squares of household head & 0.0001 & 0.58 & 0.5650 \\
\hline Environmental factors & & & \\
\hline Access to all season road & 0.0543 & 0.87 & 0.3870 \\
\hline Electricity access & -0.0639 & -1.05 & 0.2920 \\
\hline Access to safe water & -0.0048 & -0.09 & 0.9240 \\
\hline Community health & $0.2097 * * *$ & 4.38 & 0.0000 \\
\hline Distance from village to hospital & 0.0005 & 0.36 & 0.7200 \\
\hline Access to market & $0.1833^{* *}$ & 2.07 & 0.0380 \\
\hline Constant & $-1.4223 * * *$ & -4.63 & 0.0000 \\
\hline Number of observations & 8293 & & \\
\hline LR chi ${ }^{2}$ (8) & 0.0000 & & \\
\hline Prob > chi ${ }^{2}$ & 0.0383 & & \\
\hline Pseudo R ${ }^{2}$ & & & \\
\hline
\end{tabular}

(Notes) (i) The superscripts *,**, and *** denote rejection at 10, 5, and $1 \%$ critical values.

(ii) $G i$ is a latent factor that determines whether a monetary-valued household welfare change $(G i)$ by AFTA is positive or negative. Factors with positive (negative) coefficients indicate that these factors are positively (negatively) associated with the probability that these households increase their welfare by AFTA.

(Source) Authors' calculations based on LECS 4.

In regard of Household characteristics, the results demonstrate that all of the variables of household characteristics have an insignificant impact on welfare, which means that these characteristics hold less influence over absolute welfare gains or losses. This is in contrast with the study of Anderssson, Engvall, and Kokko (2005).

Finally, in Environmental factors, the results of the study indicate that there are only two environmental factors out of six-village access to health services and marketsthat are statistically significant and positively related to welfare. 


\section{Conclusion}

The impact of trade liberalization on poverty is of major interest to academics and policy makers at the local and international levels. There are some remaining questions as to whether or not trade liberalization is good for poor households. In Laos, the AFTA could have positive and negative impacts on poverty depending on various factors, including the characteristics of households. There is therefore significant concern as to whether trade liberalization, especially the provisions of AFTA, raises or alleviates poverty. However, very few studies exist that focus on the impacts of AFTA on poverty in Laos. The main objective of this study is to assess those impacts with a CGE model (GTAP), micro-simulation, and a logit model.

The GTAP simulation results show that the direct impact of tariff cuts is minimal. However, the indirect effects from AFTA, such as the improvement of trade facilitation and the promotion of FDI, are expected to be much larger. Laos experiences the growth of a much more significant trade deficit from AFTA. AFTA increases not only real GDP and welfare in Laos but also increases its trade deficit and creates winners and losers in production outputs. The AFTA also contributes to poverty reduction in terms of increasing wages for both skilled and unskilled labor and it does not increase income inequality in Laos.

The FDI inflows to Laos have increased since the introduction of the FDI promotion laws in 1994. More than 70\% of the capital inflow into Laos was for the resource sector, such as mining and hydropower, from the 1980s to the 2010s (Kyophilavong 2009). Therefore, the Lao government should promote more FDI that is diversified. In order to achieve that goal, it is important to improve the regulations and laws to meet the needs of FDI. In addition, it is important to consider providing more tax incentives and other incentives for FDI. The development of Special Economic Zones (SEZ) is also an important factor in attracting FDI to the manufacturing and agricultural sectors (Nozaki and Kyophilavong 2015) to promote long-term economic growth to reduce poverty. Second, it is important to improve trade facilitation. Laos is a land-locked country and is facing physical and institutional issues on trade facilitation. The time and costs for exports and imports are higher than the averages in East Asia \& Pacific, Cambodia, and Thailand. Therefore, policy makers should improve trade facilitation in order to gain more benefits from AFTA.

From the results of the micro-simulation, the impacts of AFTA on welfare are 
positive on the national level and for urban and rural households on the whole. The AFTA also reduces inequality at the national level but its impacts on inequality are heterogeneous across the regions. The logit model indicates that the beneficiaries of AFTA are determined by whether households have access to irrigation, the number of livestock, the number of literate members of the household, the education level of the household's head, the land area of the household, and access to the community and a market. From this finding, we recommend the following: First is to increase the irrigated areas under cultivation. These areas account for only $28 \%$ of the total area under cultivation. Even though the irrigated areas under cultivation have declined by $3 \%$, they accounted for only $12 \%$ of all of the agricultural land in 2012 . Irrigated areas are an important factor in reducing poverty and income gaps because irrigation could allow farmers to produce crops during dry seasons for commercial proposes. Therefore, the Lao government should increase these areas especially in poor rural areas. Second is to improve education at all levels. The promotion of primary school education and higher education are a priority of the Lao government (GoL 2015). However, the education level is still low especially in rural areas. For instance, the adult literacy rate is relative low and accounted for about $72 \%$ of the adult populace in 2006 (World Bank 2016a). Moreover, the investment in education is still low and accounted for $15 \%$ of the government's expenditure during 2011 2015 (World Bank 2016b). Because the literacy of household members and the education level of household heads play important roles in increasing the welfare from trade liberalization, the government should invest more on education, especially in rural areas. Third is supporting the use of chemical fertilizers. Agriculture productivity is still low in Laos. The average rice production was 1.76 tons per hectare in 2012. There are a number of reasons for this low productivity. One of the important factors might be the lack of chemical fertilizers due to the high cost of chemical fertilizers. Therefore, it is important to support farmers in the use of more chemical fertilizers through the elimination of import restrictions and through subsides to support a reduction in the price of chemical fertilizers. 


\section{References}

Andersson, Magnus, Anders Engvall, and Kokko Ari. "Determinants of Poverty in Lao PDR." EIJS Working Papers Series, European Instiute of Japanese Studies, Stockholm School of Economics, 2006.

Abbott, Philip. "Trade and Development: Lessons from Vietnam's Past Trade Agreement." World Development 37, no. 2(2008): 341-353. doi.org/10.1016/j.worlddev. 2008.04.005.

Abler, David, Rodgiguez Adrian G, and Shortle James S. "Parameter Uncertainty in CGE Model of Environmental Impact of Economic Policies." Environmental and Resource Economics 14 (1999): 75-94.

Adams D, Philip. "Interpretation of Results from CGE Models such as GTAP." Journal of Policy Modeling 27 (2005): 941-959. doi.org/10.1016/j.jpolmod.2005.06.002.

Adams F, Gerard. "Measuring the impact of AFTA: An Application of a Linked CGE System." Journal of Policy Modeling 17, no.4 (1995): 325-365. doi.org/10.1016/01618938(94)00035-E.

Ariyasajjakorn, Danupon, Ganderb James P, Ratanakomutc Somchai, Reynoldsb Stephen E. "ASEAN FTA, Distribution of Income, and Globalization." Journal of Asian Economics 20 (2009): 327-335. doi.org/10.1016/j.asieco.2009.02.009.

Athukorala, Prema-Chandra and Menon Jayant. "AFTA and the Investment-Trade Nexus in ASEAN." ASEAN Economic Bulletin (1997): 159-157. DOI: 10.1111/14679701.00064 .

Binh, Nguyen Nhu and Haughton, Jonathan. "Trade Liberalization and Foreign Direct Investment in Vietnam.” ASEAN Economic Bulletin 19, no. 3 (2002): 302-318.

Brockmeier Martina. "A Graphical Exposition of the GTAP Model." GTAP Technical Paper, Purdue University: Center for Global Trade Analysis, 1996.

Brown, Drusilla K and Stern, Robert. M. "Measurement and Modeling of the Economic Effects of Trade and Investment Barriers in Services." Review of International Economics 9, no. 2 (2001): 262-286. DOI: 10.1111/1467-9396.00278.

Chen, Shaohua and Ravallion Martin. "Welfare Impacts of China's Access to the World 
Trade Organization.” The World Economic Review 18, no.1 (2004): 29-57. doi: 10.1093/ wber/lhh031.

Chen Shaohua and Ravallion Martin. "Household Welfare Impacts of China's Access to the World Trade Orgnization." Policy Research Working Paper, WPS3040, The World Bank, 2003.

Dollar, David and Kraay Aart. "Trade, Growth, and Poverty." the Economic Journal 114, no. 493 (2004): 22-49. DOI: 10.1111/j.0013-0133.2004.00186.x

Dollar, David, “Outward-Oriented Developing Economies Really Do Grow More Rapidly: Evidence from 95 LDCs, 1976-1985," Economic Development and Culture Change, 40:3 (1992), 523-544.

Fane George. "Trade Liberalization, Economic Reform and Poverty Reduction in Lao PDR." Journal of the Asia Pacific Economy 11, no. 2 (2006): 213-226.

Frankel, J. Jeffrey and Romer David. "Does Trade Cause Growth?" American Economic Review 89, no. 3 (1999): 379-399.

Fukase, Emiko and Winters L Alan. "Possible Dynamic Effects of AFTA for New Member Countries." World Economy (2003): 853-871. DOI: 10.1111/1467-9701.00551

Fukase Emiko and Martin Will. "Economic Effect of Joining The ASEAN Free Trade Area (AFTA): The Case of The Lao People's Democratic Republic." Working Paper, Washington DC, USA: World Bank, 1999.

GoL (The Government of Laos). $6^{\text {th }}$ National Socio Economic Development Plan (NEDP) for 2006-2010. Vientiane, Lao PDR: Committee of Planning and Investment, 2006.

GoL (The Government of Laos). $8^{\text {th }}$ Five-year National Socio-Economic Development Plan (2015-2020). Vientiane, Lao PDR: Ministry of Planning and Investment, 2015.

GoL (The Government of Laos). The National Growth and Poverty Eradication Strategy (NGPES). Vientiane, Lao PDR: Committee of Planning and Investment, 2004.

Hanslow Kevin. J. “A General Welfare Decomposition for CGE Models.” GTAP Technical Paper No.19, Purdue University, Center for Global Trade Analysis, 2000.

Heinrich, Jeffery and Konan Denise. Eby. "Prospects for FDI in AFTA." ASEAN Economic Bulletin 18, no. 2 (2001): 141-160. 
Hertel, Thomas. W. (ed). Global Trade Analysis: Modeling and Applications. Cambridge: Cambridge University Press, 1997.

Hertel, Thomas. W, Walmsley Terrie, and Itakura Ken. "Dynamic Effects of the "New Age Free Trade Agreement between Japan and Singapore." Journal of Economic Integration, 16, no. 4 (2001): 446-484.

Khan, Habibullah and Tongzon Jose. L. "The Challenges of Economic Integration for Transitional Economies of Southeast Asia: Cope with Revenue Losses." ASEAN Economic Bulletin 22, no. 3 (2005): 266-283.

Kyophilavong, Phouphet and Takamatsu Shinya. "Laos' World Trade Organization Accession and Poverty Reduction." Paper presented at the Thirteen Annual Conference on Global Economic Analysis, Penang, Malaysia, June 9-11, 2010.

Kyophilavong, Phouphet and Toyoda Toshihisa. "Impacts of Foreign Capital Inflows on the Lao Economy." In Empirical Research on Trade and Finance in East Asia, ed. Toyda Toshihisa. Hiroshima: Hiroshima Shudo University, 2008.

Kyophilavong Phouphet. "Can Laos Gain Benefit by Joining AFTA? How Much? A CGE Model Approach." Academic Journal of National University of Laos 1, no. 1 (2006): $1-17$.

Lakatos, Csilla and Walmsley Terrie. "Investment Creation and Diversion Effects of the ASEAN-China Free Trade Agreement.” Economic Modelling 29 (2012): 766-799, doi:10.1016/j.econmod.2012.02.004.

Kyophilavong, Phouphet. "Mining Sector in Laos.” BRC Discussion Paper Series No. 18, Bangkok Research Center (BRC), IDE-JETRO, 2009.

Minor, Peter and Tsigas Marinos. "Impacts of Better Trade Facilitation in Developing Countries: Analysis with a New GTAP Database for the Value of Time in Trade" Paper presented at the 11th Annual Conference on Global Economic Analysis, Helsinki, 12-14 June, 2008.

Menon, Jayant. "Transitional Economies in Free Trade Areas: Lao PDR in the ASEAN free Trade Area." Journal of the Asia Pacific Economy 4, no. 2 (1999): 340-364. DOI:10.1080/13547869908724685

Narayanan, G., Badri, Angel Aguiar and Robert McDougall. Global Trade, Assistance, 
and Production: The GTAP 8 Data Base. Center for Global Trade Analysis, Purdue University, 2012.

Nozaki, Kenji and Kyophilavong Phouphet. "Progress and Prospect of SEZs in Lao PDR." In Progress Report on the Potentials on the Indochina Economic Zone, ed. the Economic and Social Research Institute (ESRI), ESRI, 2015.

Oh, Jeong-Soo and Kyophilavong Phouohet. "Does ASEAN-Korea FTA Reduce Poverty in Laos? The Roles of FDI and Trade Facilitation." Journal of Social Development Sciences 5, no. 2 (2014): 50-57.

Park, Innwon. "Regional Trade Agreements in East Asia: Will They be Sustainable." Asian Economic Journal 23, no. 2 (2009): 169-194. DOI: 10.1111/j.14678381.2009.02008.x.

Park, Innwon. "East Asian Regional Trade Agreements: Do They Promote Global Free Trade?" Pacific Economic Review 11, no. 4 (2006): 547-568. DOI: 10.1111/ j.14680106.2006.00334.x.

Ravallion, Martin. "Looking Beyond average in the trade and poverty debate." World Development 34, no. 8(2006): 1374-1392. doi:10.1016/j.worlddev.2005.10.015

Ravallion, Martin, and Lokshin Michael. "Winners and Losers from Trade Reform in Morocco." In The impact of Macroeconomic Policies on Poverty and Income Distribution: Macro-Micro Evaluation Techniques and Tools, ed, Bourguignon, Bussolo et al. Washington DC: World Bank, 2008.

Stone, Stone and Strutt Anna. "Transportation Infrastructure and Trade Facilitation in the Greater Mekong Subregion.” ADBI Working Paper No.130, Asian Development Bank, 2009 .

Warr, Peter. "Road and Poverty in Rural Laos: An Econometric Analysis." Pacific Economic Review 15, no. 1 (2010): 152-169. DOI: 10.1111/j.1468-0106.2009.00494.x.

Warr, Peter. "LaoGEM: A General Equilibrium Model of the Lao Economy." Working Paper, Australian National University, 2007.

Winter, L. Alan. "Trade Liberalization and Economic Performance: An Overview." The Economic Journal 114, no. 493 (2004): F4-F21. DOI: 10.1111/j.0013-0133.2004.00185. $\mathrm{X}$ 
WB (World Bank) and DOS (Department of Statistics), "Poverty in Lao PDR 1992/32007/8," Department of Statistics, World Bank, Vientiane, Lao PDR, 2009.

World Bank, "Development with a Rapidly Expanding Natural Resources Sector

: Challenges and Policy Options for Laos," the World Bank, 2010.

World Bank, "Lao PDR: Doing Business 2016 -Measuring Regulatory Quality and Efficiency-," World Bank Group Flagship Report, World Bank, 2016 a.

World Bank. World Development Indicators.Washing the World Bank, Accessed in January 10, 2016b. http://data.worldbank.org/data-catalog/world-developmentindicators.

Zhang Xiao-guang and Verikios George. "Armington Parameter Estimation for a Computable General Equilibrium Model: A database Consistent Approach.” Working Paper, Economic Research Centre, Economics Program, The University of Western Australia, 2006. 


\section{Appendix 1: Variable definitions}

\begin{tabular}{|c|c|c|}
\hline Variables & Definition & Unit \\
\hline \multicolumn{3}{|l|}{ Dependent Variables } \\
\hline$G i$ & $\begin{array}{l}\text { Gi measures household gains or losses } \\
\text { in welfare from AFTA }\end{array}$ & gains $=1 ;$ lose $=0$ \\
\hline \multicolumn{3}{|l|}{ Explanatory variables } \\
\hline \multicolumn{3}{|l|}{ Factors of production } \\
\hline Irrigation access & Irrigation access to village & yes $=1$; other $=0$ \\
\hline Number of cattle & Number of cattle per household & Number \\
\hline Number of buffalo & Number of buffalo per households & Number \\
\hline Number of pigs & Number of pigs per household & Number \\
\hline Literate total & Total number of literate in household & person \\
\hline Literate females & Literate females & person \\
\hline Education & Education level of household head in years & year \\
\hline Adults & Number of adults in household & person \\
\hline Rice farm land & Rice farm land area of household & hectare \\
\hline Other cultivation land & Other cultivation land area of household & hectare \\
\hline Lowland area & Village located at lowland area & hectare \\
\hline Chemical use for planting & Chemical use for planting & yes $=1 ;$ other $=0$ \\
\hline Business & Household owned business & yes $=1$; other $=0$ \\
\hline \multicolumn{3}{|l|}{ Household characteristics } \\
\hline Dependency ratio & Dependency ratio & ratio \\
\hline Male head of household & Male head of household & yes $=1$; other $=0$ \\
\hline Age of household head & Age of household head & year \\
\hline Age squares & Age squares of household head & year \\
\hline \multicolumn{3}{|l|}{ Environmental factors } \\
\hline Access to all season Road & Access to all season road & yes $=1$; other $=0$ \\
\hline Electricity access & Electricity access & yes $=1$; other $=0$ \\
\hline Access to safe water & Safe water access & yes $=1 ;$ other $=0$ \\
\hline Community health & Community health access & yes $=1$; other $=0$ \\
\hline Distance to hospital & Distance from village to hospital & $\mathrm{km}$ \\
\hline Access to market & Village access to market & yes $=1$; other $=0$ \\
\hline
\end{tabular}

